International Review of Social History 43 (1998), pp. I-29

(C) 1998 Internationaal Instituut voor Sociale Geschiedenis

\title{
Guildsmen, Entrepreneurs and Market Segments: The Case of the Garment Trades in Antwerp and Ghent (Sixteenth to Eighteenth Centuries) ${ }^{\mathrm{I}}$
}

\author{
Harald Deceulaer
}

Summary: The present essay links the social, institutional and cultural approaches of guilds and guildsmen with their daily economic practice. Using as the point of departure a case study of the Antwerp and Ghent garment trades during the sixteenth to eighteenth centuries, a preliminary model is presented, stressing the interrelatedness between divergent strategies, behavioural practices and specific market segments. It is argued that the choice of artisans for a certain market segment implied path dependency and, hence, influenced their investment patterns, their labour relations, their attitude towards the guild, and their personal representation in daily life.

Much of recent historical writing on urban artisans and the early modern guilds has changed our perception dramatically. Unlike their previous portrayals as obsolescent, moribund phenomena, guilds are nowadays depicted as multiform, flexible organizations. ${ }^{2}$ It has become almost common knowledge that rules in normative statutes were not necessarily - or were seldom objective descriptions of social and economic reality. ${ }^{3}$ Subcontracting, markets and sometimes even capitalism are considered to be part and parcel of the world of the guilds.

Nevertheless, the precise relation between markets, guilds and artisans has remained rather unclear. While we may be aware of how guild regulation did not work, we know little about how it did. The relation between

I. The first version of this article was presented at a seminar of the Belgian Association of SocioEconomic History, Brussels, 8 November 1996 and during the ESTER seminar on Guilds and Guildsmen in European Towns (sixteenth-nineteenth centuries), Amsterdam, I3-16 November 1996. I am grateful to all the participants in these seminars.

2. See among others Michael Sonenscher, Work and Wages, Natural Law, Politics and the Eighteenth-Century French Trades (Cambridge, 1989); Steven L. Kaplan, Le meilleur pain du monde. Les boulangers de Paris au XVIIIe siècle (Paris, I996); James R. Farr, "On the Shop Floor: Guilds, Artisans and the European Market Economy, I350-1750", Journal of Early Modern History, I (1997), pp. 24-54.

3. Jean-Pierre Sosson, "Les Métiers: Norme et réalité. L'exemple des anciens Pays Bas méridionaux au XIVe siècles", in J. Hamesse and C. Muraille-Samaran (eds), Le Travail au Moyen Âge (Louvain-la-Neuve, 1990), pp. 339-348. 
markets and institutions is indeed a complex, multifaceted problem. The breathtaking plurality, multiformity and fragmentation in recent research underlines the major differences between guildsmen with respect to social status, labour relations, mobility, family strategies, and cultural attitudes and standards. As a result, assigning general social and cultural identities to artisans or guildsmen becomes difficult if not impossible. Scholars have argued that the a priori images of the world of the artisans need to be replaced by a micro-sociology of urban society. ${ }^{4}$

In this essay I will argue that some of the economic, social and cultural approaches of early modern urban artisans can be connected. As a possible approach to differentiating guilds, I present a preliminary model based on a case study of the garment trades in two cities of the southern Netherlands. The interrelatedness between the divergent strategies, behavioural practices and specific market segments of the guildsmen involved will be stressed. The argument is that the choice of artisans for a certain market segment had important implications. By making this choice, the artisans and entrepreneurs under study set forth on a path ${ }^{5}$ that influenced their investment patterns, their labour relations, their attitude towards the guild, and their personal representation in daily life. These different elements were not the result of haphazard, personal decisions. They were structured by their social and economic position on their specific markets. Accordingly, this article will establish links between different aspects in the lives of early modern artisans (markets, investments, status, guilds).

The daily economic practice of guildsmen is the point of departure. For the garment trades - the second most important economic branch in the cities of the Ancien Régime as far as employment is concerned - I will investigate who offered which products and the consequences of this situation for their strategies regarding economic and social capital. My research covers two large cities in the southern Netherlands from the late sixteenth till the eighteenth centuries (Ghent's population varied from 30,000 to 50,000; Antwerp had roughly 50,000 to 70,000 inhabitants). If possible, comparisons with other sectors will be made to test the hypotheses and arguments put forward for the garment trades. The preliminary model presented here is - as with all models - a simplification of reality, which obscures certain elements. A proper account of the differences in time and space would exceed the scope of this article. ${ }^{6}$

4. Among others by Philip Benedict, "French Cities from the Sixteenth Century to the Revolution: An Overview", in idem (ed.), Cities and Social Change in Early Modern France (London, 1989), pp. 19-20; Claire Dolan, "The Artisans of Aix-en-Provence in the Sixteenth Century: A Micro-Analysis of Social Relationships", in ibid., pp. 174-194.

5. See, about the concept of "path-dependency", Paul A. David, "Why are Institutions the 'Carriers of History"? Path Dependence and the Evolution of Conventions, Organizations and Institutions", Structural Change and Economic Dynamics, 5 (1994), pp. 205-219.

6. These are treated in my forthcoming Ph.D. thesis on the garment trades in Antwerp, Brussels and Ghent from the sixteenth to the eighteenth centuries. 
This essay's principle of relating market types to specific industrial cultures $^{7}$ is inspired both by Anglo-Saxon socio-economic historiography and by a few studies in French social and economic theory. A few aspects deserve emphasis. Research on the Industrial Revolution has turned the spotlight away from the concentration of means of production or the increasing fixed capital formation. Several types of liquid capital were far more important until the end of the nineteenth century. ${ }^{8}$ Analysing the divergent composition of capital therefore seems essential: not only the elements acknowledged by economic theory, such as owning property, stock or receivables, but also the guildsman or entrepreneur's status and reputation are relevant. ${ }^{9}$ In this respect, Bourdieu's differentiation between economic, social and cultural capital may be useful. Economic capital can immediately be turned into money and constitutes "capital" in the conventional sense of the word. Social capital consists of resources connected to a network of relations based on obligation, gratitude or common membership of a group. Cultural capital consists of skills, knowledge or education. Social and cultural capital can under certain circumstances be turned into economic capital. ${ }^{\text {IO }}$ In recent economic theory, French "convention economists" have tried to introduce forms of coordination that transcend markets and prices. ${ }^{\text {II }}$ The neoclassical functioning of markets with prices as the crucial element (the "market convention") is not the only possible variable in the process of buying and selling or of assessing quality. ${ }^{\text {I2 }}$ This multitude of approaches may help bridge the artificial gap between economic and social history.

The following examination of a few major groups in the garment industry delineates their market sectors by establishing the types of products they manufactured, the prices they charged and their distribution outlets. Next, I place these groups in their social context and investigate the influence of their market sector on their investment strategies, their labour relationships,

7. For example, Maxine Berg, "Markets, Trade and European Manufacture", in idem (ed.), Markets and Manufacture in Early Industrial Europe (London, 199I), pp. 2-26; John Small, "Manufacturer or Artisan? The Relationship Between Economic and Cultural Change in the Early Stages of the Eighteenth-Century Industrialisation", Journal of Social History, 25 (1992), pp. 79I-8I4.

8. François Crouzet, "Editor's Introduction", in idem (ed.), Capital Formation in the Industrial Revolution (London, 1972) pp. 13-19, 37, 45; Maxine Berg, Patricia Hudson and Michael Sonenscher, "Introduction", in idem (eds), Manufacture in Town and Country Before the Factory (Cambridge, 1983), pp. 5-13; Patricia Hudson, The Industrial Revolution (London, 1992), pp. 25-26. 9. Theodore M. Safley and Leonard N. Rosenband, "Introduction", in idem (eds), The Workplace Before the Factory. Artisans and Proletarians, I500-I800 (Ithaca and London, 1993), pp. 2-3.

Io. Pierre Bourdieu, "Economisch kapitaal, sociaal kapitaal, cultureel kapitaal", in idem, Opstellen over smaak, habitus en het veldbegrip gekozen door Dick Pels (Amsterdam, 1989).

II. For example, Laurent Thévenot, "Economie et politique de l'entreprise; économies de l'efficacité et de la confiance", in Luc Boltanski and Laurent Thévenot (eds), Justesse et justice dans le travail (Paris, 1989), pp. 135-207. André Orléan, "Introduction: Vers un modèle général de la coordination économique par les conventions", in idem (ed.), Analyse économique des conventions (Paris, 1990), pp. 9-40.

I2. Laurent Thévenot, "Equilibre et rationalité dans un univers complexe", Revue Economique, 2 (1990), pp. I47-I97. 
their attitude towards their guild and their method of organizing their funerals.

\section{GUILDSMEN AND MARKET SECTORS IN THE GARMENT INDUSTRY}

\section{Who sold what?}

The lack of preliminary studies on the garment industry in the southern Netherlands obviously precludes any outline of different market sectors based on a priori classifications and calls for empirical research. This essay does not address groups such as shoemakers, cloakmakers, wigmakers, or glovers. I will focus on the three groups that dominated in quantitative respects for the greater part of the period under study: the tailors, the second-hand dealers and the hosiers. The important differences between these groups form a good starting-point for historians studying multiformity.

Most tailors delivered goods to order and rarely had any significant stock on hand. ${ }^{13}$ Usually, the client supplied the cloth, and the tailor provided only buttons, ribbons, thread and fabric for the lining. ${ }^{\text {I4 }}$ Any cloth supplied by the tailors had to be purchased from textile dealers, as tailors were excluded from the retail market for fabric. ${ }^{\text {I5 }}$ Textile prices determined the cost of clothing. Tailors generally made bigger outer clothes, which required large quantities of relatively costly fabric. Customers who decided to have garments made are unlikely to have approached a tailor arbitrarily. A tailor's skills, experience and reputation were therefore crucial, as the client needed to have faith in the tailor to whom he was entrusting his fabric. Cutting

13. Out of forty probate inventories of tailors from Antwerp, Brussels and Ghent, only seven had any stock (data from my forthcoming Ph.D. thesis). In a sample of sixty-six tailors from Yorkshire, Halifax, Nottinghamshire and Lancashire seven tailors owned stock: J. Styles, "Clothing the North: The Supply of Non-Elite Clothing in the Eighteenth-Century North of England", Textile History, 25 (1994), p. I42.

14. Frida Sorber, "Kledij in Antwerpse archieven uit de zeventiende eeuw", in Antwerpen in de XVIIde eeuw (Antwerp, 1989), p. 459; Isabelle H. Van Eeghen, De Gilden. Theorie en praktijk (Bussum, 1965), p. 50; Patricia Van den Eeckhout, "Onderaanneming en huisarbeid in Westeuropese hoofdsteden. Twee eeuwen flexibiliteit in de Kledingindustrie (Igde-2oste eeuw)", Tijdschrift voor Sociale Geschiedenis, 20 (1994), p. 397.

I5. Stadsarchief Antwerpen (hereafter SAA), Gilden en Ambachten (hereafter GA) 40I9, 2 July I584 and GA 3275, I7 August 1672 (ban on the retail trade in fabric for tailors and second-hand dealers); SAA, GA 4003, 24 November 1608 and Privilegekamer (hereafter PK) IOI5, 3 March 1649 (ban on making clothes with fabric not bought from a textile dealer). Only from the late eighteenth century onwards were tailors involved in the retail trade in textiles: Sven Steffens, "Schneiderei, Konfektion, Heimarbeit. Aspekte der Zerfalls und der Umstrukturierung eines städtischen Handwerks in Belgiën (19. bis frühes 20. Jahrhundert)", Tijdschrift voor Sociale Geschiedenis, 20 (I994), p. 432. 
the cloth wrong or embezzling a piece could drive up the cost considerably. Many old proverbs and sayings contain such accusations against tailors. ${ }^{16}$ The title Le Tailleur Sincère (The honest tailor) of a seventeenth-century manual instructing tailors on cutting cloth and making garments was far from coincidental. ${ }^{17}$ Some tailors served the same families for years and would receive payment annually or semi-annually. ${ }^{18}$ Tailors working for the Court or an aristocratic clientele, especially, often had to wait a long time for payment. ${ }^{19}$ In 1622, for example, the Antwerp tailor Willem van Swol had 758 guilders outstanding from various clients. ${ }^{20}$ Credit was therefore essential to every tailor's business. Because their customers generally paid late, tailors also needed access to credit. To this end, a good moral and financial reputation within the local community was crucial. ${ }^{21}$ Custom tailors generally catered to the local market and maintained direct contact with their clientele. They appear to have had very few opportunities to sell to regional markets.

Some tailors also produced ready-made clothing. The size of the market for ready-made clothing before the nineteenth century is a subject of debate. Several historians have argued that various garments were sold in England as ready-made items by the eighteenth century - and even as early as the seventeenth century according to some..$^{22}$ Other authors consider the empirical evidence substantiating these assertions rather flimsy. ${ }^{23}$ According to Belgian historians, ready-made garments entered the market only around

I6. For example, "die kleermaker heeft grote ogen aan zijn schaar" (this tailor cabbages the cloth), or the nursery rhyme "Kleermaker lapjesdief, G'het gestolen mijn gerief" (Tailor, thief of cloth, you have stolen my gear), in J. Heinsius, Woordenboek der Nederlandsche taal, VII ('s-Gravenhage and Leiden, 194I), p. 3687. See for numerous examples of such complaints, Van Eeghen, De Gilden, p. 50.

17. Bernard Boullay, Le Tailleur Sincère contenant ce qu’il faut observer pour bien tracer, couper \& assembler toutes les principales pieces qui se font dans la profession des tailleurs (Paris, 167I).

I8. Sorber, "Kledij", p. 459; Van Eeghen, De Gilden, p. 54.

19. John Brewer, "Commercialisation and Politics", in Neil McKendrick, John Brewer and John

H. Plumb (eds), The Birth of a Consumer Society. The Commercialisation of Eighteenth-Century England (London, 1982), pp. 198, 203-212; Jacqueline Boucher, "Le vêtement à la cour des derniers Valois", IIze Congrès national des Sociétés savantes (Lyon, 1987), p. 333.

20. SAA, Notariaat (hereafter N) I197, February 1622. An unskilled journeyman bricklayer had to work 1,263 (summer) days for this sum.

2I. Brewer, "Commercialisation", pp. 209-2I2; C. Muldrew, "Interpreting the Market: The Ethics of Credit and Community Relations in Early Modern England", Social History, I8 (1993), pp. 177179 .

22. Neil McKendrick, "The Commercialisation of Fashion", in McKendrick et al., Birth of a Consumer Society, pp. 34-99, esp. pp. 42, 83, 86; M. Spufford, The Great Re-Clothing of Rural England. Petty Chapmen and Their Wares in the Seventeenth Century (London, 1984), pp. I0O-IO4, 107; B. Lemire, Fashion's Favourite: The Cotton Trade and the Consumer in Britain, 1660-1800 (Oxford, 1991), pp. I80-183, 198.

23. Lorna Weatherill, "Consumer Behaviour, Textiles and Dress in Late Seventeenth and Early Eighteenth Centuries", Textile History, 22 (1991), p. 305; Hudson, The Industrial Revolution, pp. I76-I78; Styles, "Clothing", p. I40. 
I840. This discussion requires a set definition of "ready-made clothing". Nineteenth-century ready-made clothing is generally associated with the rise in labour segmentation, employment of unskilled or semi-skilled workers, expansion of the cottage industry and the growing share of women in the labour market. ${ }^{24}$ This specifically nineteenth-century form of ready-made clothing hardly existed in the Ancien Régime, at least as far as manufacturing large garments was concerned. If ready-made clothing is defined as production for stocks rather than by special order, however, this industry emerged earlier. Some tailors did indeed produce garments "for sale" in the sense that they made garments or had them made with the intention of finding buyers in their shops or on the market. This group, which was known as the nieuwwerkers ("new workers"), supposedly engaged "not in making garments on order, but in selling garments they had made". ${ }^{25}$ They purchased their fabric themselves. At times, the distinction between new work and other sectors of the garment industry was rather fluid. Until I742, the sale of ready-made items was permitted in combination with tailor-made garments in Antwerp. ${ }^{26}$ In 1628, the nieuwwerkers were accused of buying used clothes daily and "altering them so as to be able to sell them as new items without anybody noticing their deceit". ${ }^{27}$ Even though combining the trade in used and new clothes was strictly prohibited, this practice suggests that garments "made for sale" during the seventeenth century were quite different from the standardized, ready-made products of the nineteenth century. Early modern producers of ready-made clothing in the garment industry were not very important numerically. In Ghent and Antwerp, nieuwwerkers accounted for about 5 to Io per cent of all tailors in the early eighteenth century. ${ }^{28}$

The second-hand dealers are best known for selling used garments and other second-hand goods in public. Nevertheless, second-hand dealers also sold new clothes in Ghent throughout the Ancien Régime, in Antwerp until

24. Van den Eeckhout, "Onderaanneming en huisarbeid", pp. 399-405; Steffens, "Schneiderei", pp. $433-436$.

25. SAA, Processen (hereafter P) A758, I694, deduction.

26. SAA, GA 4003, 24 November I608. From 1742 onwards, the Antwerp nieuwwerkers had to choose between ready-made clothing, or working on order: SAA, GA 4275, 20 April I742. The fact that some custom work tailors, mercers or second-hand dealers offered an assortment of ready-made clothes in the eighteenth century has been noted for England by Stanley Chapman, "The Innovating Entrepreneurs in the British Ready-Made Clothing Industry", Textile History, 24 (1993), p. 5, and for Central Europe by Irene Turnea, "The Tailor's Guilds in Central Europe between the 16th-I8th Centuries", Drittes Internationales Handwerkgeschichtliches Symposium (Vezprem, I987), p. 264.

27. SAA, PK 920, 7 July I628. A similar accusation in PS 3657, 1629, response.

28. Between I7I4 and I724, I23 tailors joined the guild in Antwerp, of whom only seven were nieuwwerkers (which means they sold ready-made clothes): SAA, GA 4I28, I724-1725. In 1739 in Ghent, 24 nieuwwerkers were counted out of 226 tailors: Stadsarchief Gent (hereafter SAG), Reeks I99, 6, I739 and Reeks I56, 3, 8, I738. 
1742, and in Louvain for most of the eighteenth century. ${ }^{29}$ This practice was also common in London and Paris. ${ }^{30}$ Clothes were generally made by tailors for a modest fee and sold by the second-hand dealers on the market or in their shops. Unfortunately, insufficient information is available to determine the number of second-hand clothes dealers selling such readymade garments or to ascertain whether they distinguished between used goods and new ones in their selection. Several indications suggest, however, that this line of business was substantial in some periods. In 1536, the 74year-old tailor Jan Schuurman testified that he had been selling new garments to second-hand clothes dealers at the Friday market for nearly fifty years. ${ }^{31}$ In the course of the sixteenth century, this practice seems to have been commonplace: in 1568 the second-hand clothes dealers were said to "make or commission production of garments from new fabric daily". ${ }^{22}$ In I6II, the tailor Guillaume Michiels stated that he derived his income solely through daily production of jerkins for second-hand dealers. He estimated that he had supplied about 200 over the past two or three years. ${ }^{33}$ Two years later, the deans of the second-hand dealers explained that many tailors were willing to work for the second-hand dealers, because their clients paid their bills late. They claimed that "many [tailors, H.D.] could not wait for their money for so long and therefore settled for the mediocre profit they could obtain through public sales". ${ }^{34}$

It is unclear whether the second-hand clothes dealers supplied the fabric to the tailors (which would indicate that they organized a putting-out network) or whether they bought the garments ready-made from the tailors (which suggests a Kauf system). Both practices probably occurred at the same time. Guillaume Willems was a second-hand clothes dealer known for his extensive organization of subcontracting. In I62I, his stocks included 839 garments and 204 pairs of Milanese stockings. He also had a full 4,OII

29. In the course of the seventeenth century, Louvain second-hand dealers ordered new clothing from tailors "for themselves", and sold these afterwards. In 1758 they were given the official permission to sell new clothing: A. Meulemans, "Leuvense ambachten, III, De oudkleerkopers", Eigen Schoon en de Brabander, 40 (1957), pp. 65, 136.

30. Ordinances from I544 and 1655 gave Parisian second-hand dealers the right to make new clothing, as long as their value did not exceed ıo livres: A. Franklin, Dictionnaire historique des arts, métiers et professions exercés à Paris depuis le XIIIe siècle (Marseille, I987; ist pub. Paris and Leipzig, I905-I906), p. 347. At the end of the Ancien Régime, Parisian tailors complained strongly about the competition from second-hand dealers: J.G. Coffin, "Gender and the Guild Order: The Garment Trades in Eighteenth-century Paris”, Journal of Economic History, 54 (1994), p. 78r. See, for London, Beverly Lemire, "Peddling Fashion: Salesmen, Pawnbrokers, Tailors, Thieves and the Second-Hand Clothes Trade in England, c. I700-I800”, Textile History, 22 (I99I), pp. 70-72. 3I. SAG, Reeks I9I, 6 (3), I536; I9I, 4, 23 April I536 (numerous similar statements).

32. SAA, PK 64I, 20 September I568. In I587, the 80-year-old tailor Otto Van der Grundt testified that he had been working for various second-hand dealers for thirty years: SAA, Processen Supplement (hereafter PS) I502, I590.

33. SAA, N 3365, 23 September I6II

34. SAA, PA 860 and A 504, I613-1615. 
ells of fabric, which was enough for about 320 coats. Most textile records reflect relatively small quantities (II7 of the 163 listings were pieces of less than 30 ells), which shows that such purchases did not involve wholesale trade in fabric. He was clearly an able subcontractor as well, as a certain Dierick "the tailor" appears on the list of debtors. ${ }^{35}$ In 1622, his colleague Guillaume De Grande owned a workshop with a workbench, tailor's scissors, and 277 ells of fabric in small pieces. His shop contained 195 garments, and several additional cabinets and boxes stuffed with clothes were found in the kitchen, the upstairs room, and the shed outside. It may or may not have been a coincidence that the tailors Nicolaes Vos and Godevaert Govaerts owed him 57 guilders and 6 stuivers. ${ }^{36}$ Most probably, these tailors worked off their debts. ${ }^{37}$

Nevertheless, the second-hand clothes dealers did not always supply the fabric. In I6II, for example, tailor Michiel de Roy sold a jerkin to a secondhand dealer. The garment had been returned by the original client because it was too small. ${ }^{38}$ That same year, innkeeper and tailor Peter Herck from Borgerhout (a village near Antwerp) reported that he had made and sold several buffalo leather jerkins through second-hand dealers in Antwerp, but that he never received any assignments from them..$^{39}$ In these cases, tailors appear to have taken advantage of the elaborate commercial channels available through second-hand dealers.

At any rate, reports mentioned second-hand dealers purchasing new clothing from tailors daily in 1627 and $1673 .^{40}$ In 1736 , the tailors of Ghent and members of several other guilds stated that "nearly every guild in this city has an Esau" [i.e. somebody willing to sell his privileges]. Their biblical reference concerned the poor masters in their midst from whom the second-hand dealers purchased new products "at far less than their value or supposedly for a pittance" ${ }^{4 \mathrm{I}}$ Second-hand dealers sold their wares at moderate prices. Merchants at the Friday market in Ghent offered a tremendous variety of new and used clothes: "clothes for men, women, and children unable or unwilling to spend large amounts, including cloaks, suits, vests, trousers, undershirts, skirts, and light woollen garments". Other available items included all kinds of linen, "washed and pressed for men and women in all prices and qualities",

35. SAA, N I496, I62I. See Boucher, "Le vêtement", p. 339, for other examples of big stocks of clothing by second-hand dealers. Second-hand clothes dealer Guillaume de Pepyn also purchased fabric regularly and included a tailor among his debtors: SAA, W485, 29 July I62I.

36. SAA, N 3376, I October I622.

37. SAA, N I496, I62I. This phenomenon is studied by Catharina Lis and Hugo Soly, "Corporatisme, onderaanneming en loonarbeid. Flexibilisering en deregulering van de arbeidsmarkt in Westeuropese steden (veertiende-achttiende eeuw)", Tijdschrift voor Sociale Geschiedenis, 20 (I994), p. 370 and passim.

38. SAA, N 3365, I7 September I6II.

39. SAA, N 3357, I3 August I6II.

40. SAA, PA 834, I627, PK 766, I4 March I673.

4I. SAG, Reeks 156 bis 75 (I), undated item, trial in 1736 . 
shoes, gloves, knitted stockings, and caps in different colours and prices. ${ }^{42}$ Some sources even suggest a regional or national market for "old" clothes. In the early seventeenth century, the tailors from Brussels and Mechelen complained that the Antwerp second-hand dealers supplied new ready-made clothing to the second-hand dealers in Brussels and Mechelen. ${ }^{43}$ The secondhand clothes dealers of Ghent visited several annual fairs outside the city. ${ }^{4}$ The existence of commercial ties between second-hand clothes dealers in different cities is also apparent from the 1762 remark that the prohibition on importing used clothing did not apply in the other cities of "her majesty's jurisdiction". ${ }^{45}$ Second-hand clothes dealers in Ghent retained their right to sell tailor-made clothing, whereas this practice was definitively prohibited in Antwerp in $1742 .{ }^{46}$ Such differences with respect to time and place merit closer consideration. It remains unclear whether second-hand dealers were allowed to sell new garments in other cities as well. At any rate, the assertion that the putting-out system began to play a significant role in the garment industry in large cities only towards the late eighteenth century and became widespread around the mid-nineteenth century, needs qualification. ${ }^{47}$

The hosiers are the last group covered here. The stockings they produced were entirely different from the ones we wear today. In the sixteenth century, hosiers were permitted to make all types of "legwear" ${ }^{38}$ and, accordingly, they were also known as stocking and trouser makers. In those days, stockings were longer than socks today and were attached to trousers. In the sixteenth and seventeenth centuries, they were usually cut and stitched from inexpensive fabric in the Netherlands, although knitted stockings may have become more popular. ${ }^{49}$ Changing fashions eliminated the use for the

42. SAG, IGDI, 5 , I664.

43. Stadsbibliotheek Antwerpen 582577, undated petition, probably I6IO. The Antwerp secondhand dealer Guillaume Willems supplied 903 guilders worth of goods to six individuals in Mechelen, Brussels and Louvain: SAA, N I496, I621.

44. SAG, 47 registers, MM, 27 September 156I (allotment of places in the market in and outside Ghent); Reeks I56 bis, 85, 6 August 1627 (mentioning three fairs outside Ghent). They were certainly active in Bruges: M. Danneel, "Handelaarsters in oude klederen in de I6de eeuw te Brugge", Brugs Ommeland, 25 (1986), pp. 204, 207; D. Dendooven, "De handel in tweedehandsgoederen in Brugge”, unpublished manuscript, Free University of Brussels, I99I-I992 (complaints about competition from Ghent second-hand dealers in 1658 and 1718 ).

45. SAG, 47 registers, DDD, 4 March and 6 May 1762.

46. SAG, Reeks 191, 4, 2I February 1782; SAA, GA 4275, 20 April 1742; Floris Prims, Geschiedenis van Antwerpen. IX, Met Oostenrijk en onder de Franschen (I7I5-I8I4), De Economische orde (Antwerp, I942), p. 44.

47. Friedrich Lenger and Paula Lutum-Lenger, "Schneider und Schneiderinnen", in Reinhold Reith (ed.), Lexicon des alten Handwerks. Vom Spätmittelalter bis ins 20. Jahrhundert (Munich, 1990), pp. 212-214. Christopher Friedrichs, The Early Modern City, I450-I750 (London and New York, I995), pp. 99-IOO also stated that the range of the putting-out system remained rather limited in the early modern town.

48. SAA, GA 40I7, f. 268, I524; GA 4124 bis, 24 November 1588.

49. Jan Walgrave, De mode in Rubens' tijd (Antwerp, 1977), pp. 28, 31, 35. 
hosiers' monopoly on trouser production from the early seventeenth century onwards. Rather than wearing trousers in contrasting fabric, people began to prefer them in the same material as their jerkins. As a result, tailors received the right to make trousers to order as well..$^{50}$ Making and selling stockings thus became the hosiers' primary occupation. Their products were much cheaper than the items sold by tailors or second-hand clothes dealers. ${ }^{\text {II }}$ This distinction applied in even greater measure to the breech makers, who made trousers and stockings from cheap cloth. In I524, they were prohibited from using cloth that cost more than eight stuivers an ell. This ceiling was raised to 24 or 25 stuivers an ell in $16499^{52}$

Seventeenth- and eighteenth-century stocks of hosiers show that stockings were readily available for less than 20 stuivers a pair. ${ }^{53}$ Some hosiers also appear to have sold small garments, such as linen trousers and waistcoats, which rarely cost more than 15 or 20 stuivers. At these prices, their products became affordable to a much larger group. Hosiers sold their wares at sites such as the weekly markets and their trading network extended beyond the local markets. In 1604, the Antwerp hosier Fabritius Pamphi sold 6,785 guilders worth of stockings to clients throughout the southern Netherlands in Ostend, Brussels, Namur and Nivelles..$^{54}$ Of course, not all hosiers had such an impressive trading network. The ones unable or reluctant to market their products themselves appear to have engaged merchants who traded in stockings. One such merchant was Herman De Neyt, an Antwerp hosiery dealer who died in I626. His receivables amounted to 3,065 guilders and included debtors in Ghent, Bruges, Dendermonde, Emmerich, Kortrijk, Namur and Tienen. ${ }^{55}$ Hosiers frequently sold their products to mercers for subsequent resale. In 158I, the Council of Brabant upheld the right of the Antwerp mercers to sell stockings and other small garments. ${ }^{56}$ The international market also offered a wealth of sales opportunities. The aforementioned De Neyt shipped his stockings to Amsterdam, 's-Hertogenbosch and Cologne. Stockings were also exported to Spain during the sixteenth and seventeenth centuries. ${ }^{57}$

50. SAA, GA 4003, Io October 1643. Similar measures became effective in Paris: Franklin, Dictionnaire historique, p. 676.

5I. Irena Turneau, "La bonneterie en Europe du XVI au XVIIIe siècle", Annales ESC, 26 (197I), p. II2O.

52. SAA, GA 40I7, f. 268, I524. PK IOI5, 3 March I649.

53. SAA, N II86, 7 March I604, SAG, Reeks 332, 30I, I2, I4 June I70I, Reeks 332, 583, I7, I740; Reeks 332, 687, 5, I August 1759, Reeks 332, 680, 29, 28 July 1760; Reeks 332, 804, I6, 20 March I785, Reeks 332, 802, 25, 4 April I785.

54. SAA, N II86, 7 March 1604.

55. SAA, N 3380, 20 November 1626.

56. Verdict cited in SAA, PA 812, 1606.

57. Often stockings made in Tournai: Gustaaf Asaert, "From Wharf to Commercial Metropolis",

in Frans Suykens et al. (eds), Antwerp. A Port for all Seasons (Antwerp, 1986), p. 68; Roland Baetens, "Handel, geld- en bankwezen in de Zuidelijke Nederlanden, I580-1650", Algemene Geschiedenis der Nederlanden, 7 (Haarlem, 1980), p. 134. 
Within the scope of this article, a detailed discussion of the historical evolution of the Antwerp and Ghent garment trades is impossible. Among the three groups considered, the most drastic changes occurred among the hosiers. From the middle of the seventeenth century onwards, international competition increased the importance of cutting costs. The introduction of the hosier frame de-localized rural production and resulted in a concentration in manufactures in some cities. ${ }^{58}$ In the southern Netherlands, the hosier frame gradually became popular in the late seventeenth and early eighteenth centuries. ${ }^{59}$ In $\mathrm{I} 777$, local customs officers stated that "les principales fabriques de bas, bonnets tant au metier qu'au tricot qui existent dans les Pays Bas Autrichiens sont sans contredits celles de Tournai et ses environs" (the main factories for both industrial and knitted stockings and caps are unquestionably the ones in Tournai and the surrounding area) ${ }^{60}$ As a result, the number of Antwerp and Ghent hosiers and the importance of their guilds declined strongly in the eighteenth century.

This glimpse of the three groups under study makes clear that the garment trades were characterized by different types of products, different ways of assessing quality and different types of markets. A few concepts of recent economic theory can facilitate interpretation of this multiformity. The three groups can possibly be linked to three "conventions", or collective logics to coordinate resources, assess quality and reduce uncertainty for customers. In the model of the convention economists, the "market" or price-oriented convention is only one form of coordination. In the "domestic" or personoriented convention, products and qualities are situated in a sphere of local tradition and personal ties. In the product-oriented, "industrial" convention, quality is assured through standardization and technical controls. ${ }^{61} \mathrm{Of}$ course, these concepts from modern economic theory were not constructed for analysing early modern artisans or guilds in the Ancien Régime and some of them may need further elaboration and refinement. ${ }^{62}$ Nevertheless, they may sharpen our insight into the past.

58. One element in the international competition is described by Pauline Croft, "The Rise of the English Stocking Export Trade", Textile History, I8 (1987), pp. 3-16. See more in general Turneau, "La bonneterie en Europe", pp. III8-II32.

59. Eric Vanhaute, "Wolverwerking op het Turnhoutse platteland (I750-1850). Enkele bedenkingen bij het verstomd proto-industrieel debat”, Tijdschrift voor Sociale Geschiedenis, I7 (199I), p. 37.

6o. Algemeen Rijksarchief Brussel (hereafter ARA), Raad van Financiën, 4847, 2 February 1777. Succinct information in René Leclercq, Histoire de la bonneterie dans le Tournaisis (Tournai, 1958). 6I. These three conventions were emphasized in François Eymard-Duvernay, "Conventions de qualité et formes de coordination", Revue Economique, 2 (1989), pp. 329-359 and by the same author, "Coordination des échanges par l'entreprise et qualité des biens", in Orléan (ed.), Analyse économique des conventions, pp. 307-333.

62. A link between guild history and Convention Economics is explored by Harald Deceulaer and Marc Jacobs, "Qualities and Conventions. Guilds in Eighteenth-Century Brabant and Flanders. An Extended Economic Perspective", paper for B-Session Guilds, Economy and Society, Twelfth International Economic History Congress, Seville, 1998 (in press). 
It seems that second-hand dealers were "price-oriented". They made nothing themselves, but, instead, they bought old clothing in public sales and less expensive new garments from tailors, which they subsequently resold at local and regional markets. We saw that tailors generally supplied rather expensive, custom-made products for a clientele they knew well on the local market. They represent a "person-oriented" group: personal reputations, skills and local ties were crucial for them. The hosiers were more "product-oriented". They invested in raw materials and sold their cheap, standardized goods on a local and regional market. These three conventions never exist in pure forms. Compromises and internal contradictions between the different collective logics existed (e.g. subcontracting).

We will see that the differences in products, qualities and markets of the three market segments under study influenced other economic, social and institutional forms of behaviour. Before embarking on these differences, a few observations are in order concerning the relation between guilds, market segments and individuals. To some extent, an individual could combine certain activities depending on the circumstances. A tailor could work both as a subcontractor and on order from a specific client. Hosiers and nieuwwerkers could also fill special orders (although this practice was prohibited in Antwerp in 1742). Could one individual belong to several guilds or subgroups? The extensive membership rolls available for Ghent enable investigation of the frequency of dual memberships. Many of the same names appeared on both the hosiers' and the tailors' lists. Becoming a member of both trades was common and even became compulsory in 1688 . Nevertheless, the guildsmen did not serve identical market sectors: hosiers were not allowed to fill special orders, and tailors did not make stockings. ${ }^{63}$ Dual membership with other guilds was infrequent. Only r.9 and 5 per cent of the Ghent tailors belonged to the mercers' and second-hand clothes dealers' guilds, respectively. ${ }^{64}$ Since 1540 , joining a guild had been easier in Ghent than in other cities. Dual guild membership was less common in Antwerp and Brussels, ${ }^{65}$ as neither the local nor the central authorities encouraged this practice. Quite the contrary. ${ }^{66}$ Most individuals in the

63. SAG, I56 bis, 74, I, 2 I October 1687, 47 registers, XX, I5 June I688; ARA, Geheime Raad (hereafter GR), Spanish Period, I78, 28 February 1688.

64. Between 1590 and I779, 2,I34 masters joined the tailors' guild. Of this group, only forty-one appeared on the membership list of the mercers' guild and Io8 on that of the second-hand dealers: SAG, Reeks I9I, 4, Reeks I78, I-4, Reeks 199, I-5.

65. Of the 23I Brussels tailors who paid the annual dues to their guild in I734, only two also paid the annual dues to the second-hand dealers' guild: ARA, Ambachten van Brabant (hereafter AB), 55I and 88I-889. In Antwerp dual membership of the tailors' and second-hand dealers' guilds was forbidden: SAA, PK, 793, 5 and 17 November 1706.

66. Ghent tailor Mathieu Dupon was refused the exemption of the apprenticeship in the mercers' guild by the Secret Council in 1767: "L'interet de l'Etat exige que les differends métiers sont exercés par des personnes differentes afin d'augmenter par ce moien la population en manageant des resources pour un plus grand nombre de familles au moien d'attacher chacun a sa profession": 
industry also appear to have restricted their activities to the carefully prescribed confines of their market segment. In the garment trades, a guild's boundaries did not necessarily correspond to a market segment's limits. Market segments in the garment industry were rarely controlled by a single trade (e.g. nieuwwerkers and second-hand dealers could offer ready-made clothing). A guild might comprise several subgroups serving different market segments (for example, second-hand dealers offering new clothes and others trading mainly in housewares). Unfortunately, the exact number of people in the different subgroups are often impossible to determine. Every guild included one group that was either partially or entirely involved in subcontracting. These operations brought the different guilds in contact with one another: many poor tailors apparently sold their work not only to their colleagues but also to wealthier second-hand clothes dealers. The precise nature of such relationships is difficult to analyse. The numbers of subcontractors are unknown.

\section{What were the financial rewards of their activities?}

The focus on divergent types of capital, behavioural practices, and spending patterns requires an understanding of the social positions of the different groups. Antwerp's tax records from I584-1585 are the most obvious source. ${ }^{67}$ The agents on these lists are not grouped according to the different market segments in which they operated (Table I). The first distinction separates those who paid taxes from the people who were exempted because they were considered too poor. About half the second-hand clothes dealers paid taxes, compared to a third of the hosiers, and only about a tenth of the tailors. ${ }^{68}$ Tax payments reflect a similar ratio. Tailors were clearly more socially homogeneous and less affluent, while hosiers and second-hand clothes dealers tended to be wealthier. The tailors attributed their abundance and status as the poorest group in part to the specific balance of production within their market segment. Because making garments to order required little capital (the client usually supplied the fabric), most tailors' guilds were overpopulated. Tailors were generally known for their modest income and low prestige. ${ }^{69}$ Antwerp's incomplete tax files from 1747 and

ARA, GR, Oostenrijks Regime (hereafter OR), I28, 3 December 1767. See also ibid., I6 December I767 (baker could become a mercer only after leaving the bakers' guild).

67. No tax rolls remain for Ghent or Brussels. The information on Antwerp in 1584-1585 was studied by J. Van Roey, "De sociale structuren en de godsdienstige gezindheid van de Antwerpse bevolking op de vooravond van de reconciliatie met Farnese (I7 August 1585)" (unpublished Ph.D. thesis, Ghent University, 1963).

68. Ibid., pp. 3I, II2, I24.

69. Van den Eeckhout, "Onderaanneming", p. 397; John Rule, The Experience of Labour in I8thCentury Industry (London, I98I), pp. 22, 33, 36. The tailor's guild in Paris stated in 1776 that half of the 2,000 tailors were impoverished: Fabrice Piwnica, "Les résistances à l'introduction du 
Table I. Number of taxpayers and taxes paid by individuals in the garment industry, Antwerp, I584-1585

\begin{tabular}{lccccc}
\hline & Total & $\begin{array}{c}\mathrm{N} \\
\text { taxpayers }\end{array}$ & $\begin{array}{c}\text { Average } \\
\text { taxes }\end{array}$ & $\begin{array}{c}\text { Median } \\
\text { taxes }\end{array}$ & Tax range \\
\hline Second-hand dealers & 245 & $125(51 \%)$ & $2.2 \mathrm{~g}$ & $2 \mathrm{~g} 10 \mathrm{st}$ & $20 \mathrm{~g}$ \\
Hosiers & 124 & $41(33 \%)$ & $2.4 \mathrm{~g}$ & $1 \mathrm{~g} 10 \mathrm{st}$ & $20 \mathrm{~g}$ \\
Tailors & 479 & $47(9.8 \%)$ & $1.8 \mathrm{~g}$ & $1 \mathrm{~g} 10 \mathrm{st}$ & $15 \mathrm{~g}$ \\
\hline
\end{tabular}

the corporate licensing tax of 1799 reveal that tailors remained a fairly poor and socially homogeneous group. International literature confirms this impression. ${ }^{70}$

The next step is to ascertain the influence of these differences between market segments (or "conventions") and social status on the different aspects of economic and social life of the actors, and starts with a study of the investment patterns.

\section{INVESTMENTS AND REAL ESTATE}

Investment strategies by early modern artisans or entrepreneurs are difficult to comprehend and, therefore, we will focus on the most "visible" element: their purchases of real estate. During the early modern period, guildsmen in the garment industry viewed real estate acquisitions from various perspectives. Examining homeownership and the tax records for Antwerp from 1584-1585 conveys the discrepancies between the different subgroups. ${ }^{71}$ This information reveals a cross-section of the owners and tenants in the largest city in the southern Netherlands at the time (Table 2). First, I investigated the number of homeowners within a specific subgroup. Given that tailors were the poorest group and second-hand clothes dealers the wealthiest, it goes almost without saying that the second group is likely to have owned more houses. ${ }^{72}$ The homeownership among the total number of artisans per

liberalisme en France: le témoignage des mémoires des corporations en 1776", Revue d'histoire moderne et contemporaine, 40 (1993), p. 34.

70. SAA, PK 2560, 1747 and Karel Degryse, "Sociale ongelijkwaardigheid te Antwerpen in I747", Bijdragen tot de Geschiedenis, 58 (1974), pp. I37, I42; Jos De Belder, "Elementen van sociale identificatie van de Antwerpse bevolking op het einde van de I8de eeuw. Een kwantitatieve studie” (unpublished Ph.D. thesis, Ghent University, 1973-1974), p. 202; Robert W. Malcolmson, Life and Labour in England, $1700-1780$ (London, 1981), p. 64; Lenger and Lutum-Lenger, "Schneider und Schneiderinnen", p. 2 II.

7I. The following tables are based on material collected by G. de Gueldere of the City Archives of Antwerp.

72. The fact that tailors were less likely to build or own houses has been noted by Johan Dambruyne, "De private bouwconjunctuur", in idem et al. (eds), Een stad in opbouw. Gent van I540 tot de wereldtentoonstelling van I9I3 (Tielt, I992), p. 33; Lenger and Lutum-Lenger, "Schneider und Schneiderinnen", p. 2II. 
Table 2. Home ownership in Antwerp, 1584-I585

\begin{tabular}{lccccc}
\hline & Total & $\begin{array}{c}\mathrm{N} \\
\text { taxpayers }\end{array}$ & $\begin{array}{c}\mathrm{N} \\
\text { owners }\end{array}$ & $\begin{array}{c}\text { Owners/ } \\
\text { total \% }\end{array}$ & $\begin{array}{c}\text { Owners/ } \\
\text { taxpayers \% }\end{array}$ \\
\hline Hosiers & 124 & 41 & 24 & 19.3 & 58 \\
Second-hand dealers & 245 & 125 & 102 & 41.6 & 81 \\
Tailors & 479 & 47 & 61 & 17.4 & 100 \\
\hline
\end{tabular}

group indeed reflects social differences. Inspecting homeownership among the taxpayers, however, reveals different, more interesting patterns, indicating that those with the means were probably inclined to buy a house. Comparing the hosiers and the tailors suggests a very small difference if the total groups are considered. Taxpaying hosiers and tailors, however, formed the two extremes in the garment industry. While slightly over half of all taxpaying hosiers owned their home, the tailors who paid taxes were far more likely to purchase real estate. All taxpaying tailors owned their homes, and even fourteen tailors who did not pay taxes nevertheless owned their own homes. They had probably purchased their home during better times. This situation may convey the insecurity that characterized the market segments for tailors or the economic difficulties in Antwerp at the time the tax was levied.

While owning one's home may not necessarily be viewed as a true investment strategy, the purchase of a second, third, or fourth house is different. The records reflect the number of people in the aforementioned groups who owned more than one house in $1584-1585$ (Table 3). To limit distortion by differences between social groups, this table includes only those who paid more than one guilder in taxes. Members of this group presumably owned a modest capital and could afford to choose between buying a house and investing in interest-bearing loans or in their own business. Presumably, these more affluent operators within each market sector served as a reference group. Their actions are probably indicative of the course their poorer colleagues would have chosen, had they possessed the means. Again, the more affluent tailors exhibited a strong tendency to invest in real estate, whereas the group of hosiers paying as much or more in taxes did so far less often. The investment patterns seem to be linked to the product the artisans were offering. The "client-oriented" tailors made rather expensive clothes to order and were thus prevented from investing a lot in their own company. Accordingly, tailors owned the most houses in relative terms. The "price-oriented" second-hand dealers needed more capital and invested less in real estate. The "product-oriented" hosiers needed to invest substantially (e.g. in raw materials) to produce their cheap, standardized goods for a larger market. They seem to have followed an investment pattern that resembled the ones of other sixteenth- and seventeenth-century industrial entrepreneurs who 
Table 3. Number of people owning more than one house among those paying more than one guilder in taxes

\begin{tabular}{lccc}
\hline & $\begin{array}{c}\text { N paying }>1 \text { guilder } \\
\text { in taxes }\end{array}$ & N owning $>1$ house & $\%$ \\
\hline Hosiers & 37 & 7 & 18.9 \\
Second-hand dealers & 93 & 33 & 35.5 \\
Tailors & 27 & 15 & 55 \\
\hline
\end{tabular}

reinvested their profits in their own company. ${ }^{73}$ Guildsmen serving personalized and more haphazard market sectors therefore appear to have felt a greater need to secure their property than their counterparts operating in larger markets.

Whether this relationship held true for other periods or sectors is unclear. International literature reveals similar patterns elsewhere. Entrepreneurs from the metal industry in Birmingham, who specialized in the highly differentiated market of luxury products, for example, took a far more active part in the housing market than their counterparts from the textile industry in Manchester and Nottingham. Since the market for textile entrepreneurs was far broader and consisted of cheaper, standardized goods, investing in this sector was probably a more rational option, while the smaller entrepreneurs from Birmingham would have encountered disadvantages of scale far more quickly. ${ }^{74}$

The following four hypotheses summarize the differences within the garment industry with respect to real estate ownership:

I Custom tailors could invest very little surplus capital in their own market segment, as clients generally supplied the fabric, and purchasing real estate was therefore an obvious means for investment. Hosiers, however, bought their own commodities and had to maintain stock, and running their business therefore required investments. While tailors who sold readymade clothing obviously had to do likewise, their number was insufficient to affect the general pattern among their colleagues.

2 Purchasing a house or an estate sometimes provided custom tailors with a fixed income and their customers often paid their bills late. ${ }^{75}$

73. For example, the Moretus family producing books: J. Materné, "Restructuring the Plantinian Office. The Moretuses and the Antwerp Economy in a Time of Transition (Seventeenth Century)", in E. Aerts, B. Henau, P. Janssens and R. Van Uytven (eds), Studia Historica Oeconomica. Liber Alumnorum Herman Van der Wee (Leuven, 1993), p. 295, or the Antwerp textileentrepreneur Jan Nuyts: A.K.L. Thijs, "Een ondernemer uit de Antwerpse textielindustrie (ca 1512-1582)", Bijdragen tot de Geschiedenis, 5I (1968), 67.

74. Maxine Berg, "Commerce and Creativity in Eighteenth-Century Birmingham", in idem, Markets and Manufacture, pp. 19I-195.

75. Different tailors' bills show this clearly. See also Van Eeghen, De Gilden, p. 54; Sorber, "Kledij", p. 459. 
Hosiers were in quite a different situation: the market for cheap, homogeneous, small garments was considerably larger and had a faster turnover in capital than the larger, costlier attire sold by tailors. The tailors' strategy of procuring a fixed income therefore reflects a highly rational decision, given the limitations of their market segment.

3 To survive until their clients paid, tailors had to rely on various types of credit within the community. Owning a home was a standard instrument for drawing credit. ${ }^{76}$ Of course, the hosiers also needed credit, although they apparently required less real estate to be able to borrow than the poorer tailors did. As Peter Mathias has stated: "depending on the rate of return from the business, and the assurance of being able to borrow when this was necessary, it could be a wiser course to keep the capital at work in the business rather than putting it aside in a reserve fund". ${ }^{77}$

4 Homeownership among tailors was part of their strategy to cultivate trust and boost their creditworthiness and social status. Since they depended on assignments and crucial personal contact with their clients, they set great store by their reputation. A house was an appropriate status symbol. Homeowners were important people in their neighbourhood. Owning a home raised one's personal status and ensured a place in the local community's pecking order. ${ }^{78}$ Another group in the textile industry bore an interesting resemblance to the tailors: the cloth-dressers (or finishers). These guildsmen also depended on assignments and tried to cultivate as much trust and respectability as possible through their homeownership and lifestyle. ${ }^{79}$

Understandably, these four hypotheses do not reveal all aspects of buying houses. The multiple significances of acquiring a house and the wide variations in spending patterns among different groups call for circumspect conclusions about status and symbolic capital. We shall return to this last topic later. First, however, we will examine the labour relations towards journeymen of the artisans involved.

76. Hugo Soly, Urbanisme en kapitalisme te Antwerpen in de I6de ceuw. De stedebouwkundige en industriële ondernemingen van Gilbert van Schoonbeke (Brussels, 1977), p. 68; Dambruyne, "De private bouwconjunctuur", p. 28.

77. Peter Mathias, "Strategies for Reducing Risk by Entrepreneurs in the Early Modern Period", in Clé Lesger and Leo Noordegraaf (eds), Entrepreneurs and Entrepreneurship in Early Modern Times. Merchants and Industrialists within the Orbit of the Dutch Staple Market (The Hague, 1995), p. 2I.

78. David Garrioch, "House Names, Shop Signs and Social Organization in Western European Cities", Urban History, 2I (1994), p. 35.

79. Compare A.K.L. Thijs, Van "Werkwinkel" tot "fabriek", de textielnijverheid te Antwerpen, (eind Isde-begin Igde eeuw) (Brussels, 1987), pp. 338, 346. 


\section{LABOUR RELATIONSHIPS}

This section focuses on the relation between masters and hired help (not only on journeymen), especially with respect to the tailors and the hosiers. Hired help for second-hand clothes dealers was less plentiful and tended to be more involved in sales than in production. This group is only marginally important in this context. We will discuss the differences between the two groups concerning the number of employees and - more importantly - the nature of their statutes.

No conclusive accounts are available regarding the numbers of hired help employed by the different groups in the sixteenth and seventeenth centuries. Since the hosiers catered to a larger market (cheaper products), they are likely to have employed more labourers. In 1738 , the eight hosiers of Namur employed an average of nine helpers, while the tailors from this town averaged only one. ${ }^{80}$ That same year, the 226 tailors of Ghent had 133 apprentices, while the 20 stocking and trouser makers employed $47 .^{81}$ These ratios do not apply to all centres: the 17 hosiers of Brussels did not employ a single journeyman or apprentice in $1738 .^{82}$ The increasing regional differentiation had already changed the relationships dramatically.

Given the fact that they offered cheap products, the hosiers cut costs wherever possible. In the sixteenth century, some hosiers set up workshops in Antwerp's orphanage, where they employed the children. ${ }^{83}$ Another wagereducing strategy used by hosiers was to subcontract sewing to outworkers. This practice is evident from a trial between the hosiers Dyonisius Offermans and Fabritius Pamphi from 1599. Previously, we learned that Pamphi supplied stockings throughout the southern Netherlands. He owned a stock of 2,023 pairs of stockings worth 3,180 guilders. ${ }^{84}$ Offermans, a fellow hosier, pressed charges against Pamphi for issuing assignments to workers "while they were still serving the plaintiff". Pamphi responded that the workers concerned could not be bound to a single master, as they were not permanently employed at a workshop but carried out individual assignments at home. They were also "free and entitled" to "serve as many masters from their house as they could and to assemble any items cut by free masters". Subcontracting the sewing and finishing on stockings had been cus-

80. In 1738 , the 68 tailors of Namur employed 23 journeymen, 32 apprentices and 20 labourers. The eight hosiers of the town employed no fewer than 56 journeymen and 20 apprentices: J.P. Descy, "De kleren van de Naamse burgerij op het einde van de XVIIIde eeuw" (unpublished Master's thesis, Catholic University of Leuven, 1992), p. 48.

8I. SAG, Reeks I56, 3, 8, I738.

82. Karin Van Honacker, "De politieke cultuur van de Brusselse ambachten in de I8de eeuw: conservatisme, corporatisme of opportunisme?", in Catharina Lis and Hugo Soly (eds), Werken volgens de regels. Ambachten in Brabant en Vlaanderen, I500-I800 (Brussels, I994), p. 223.

83. Edmond Guedens, Het Antwerpsche Knechtjeshuis sedert zijn voorhistorisch tijdperk tot op onze dagen (Antwerp, I895), p. 67.

84. According to his probate inventory, $\mathrm{N}$ II86, 7 March I604. 
tomary for as long as anybody could remember. Offermans did not deny this, and many outworkers even confirmed the story. For example, 64-yearold Willem de Keyser testified that "not having passed his master test in that trade, he worked daily for free masters from his home and sewed stockings for all masters who used his services without being bound to any individual" ${ }^{85}$ Accordingly, the hosiers had a very flexible labour supply that they could engage or dismiss at their discretion - an option that clearly curtailed the wage costs. Legally issuing assignments to journeymen working from their homes - albeit for partial jobs - was exceptional during the Ancien Régime. While moonlighters hidden in attics or working from suburbs were commonplace, subcontracting by contemporaries to journeymen working from their homes is generally considered irreconcilable with corporatism. ${ }^{86}$ Not all outworkers were journeymen. In I600, the guild's deans decreed that the economic slump required that several masters work as helpers. ${ }^{87}$ The tendency of masters to employ other masters (known as the Handwerksinterne Verlag) existed among tailors as well.

Another difference in the labour relationships between hosiers and tailors concerned their respective views of women's labour. In 1615, some hosiers carrying out very large assignments from the military secretly employed women and girls. The hosiers' guild did not tolerate this practice and regularly pressed charges against any of its members organizing such operations. ${ }^{88}$ By the second half of the seventeenth century, the guild apparently no longer had any qualms about this issue. In I673, the tailors accused the hosiers' deans of admitting a crowd of tailors' apprentices, women and non-citizens to the guild without serving any apprenticeship and "even of telling these individuals where to fetch forged certificates for periods of apprenticeship in Bergen op Zoom and other places without hosiers guilds" ${ }^{89}$ Tailors were especially upset about this problem "when the hosiers received permission to produce all kinds of men's clothes as well". In the eighteenth century, several entrepreneurs operating in cheaper market segments also employed seamstresses. This situation indicates a clear conflict of interest between the operators in different market segments. Hosier subcontractors primarily needed a large supply of cheap labour and were less concerned with training than the tailors. They had little use for strict regulations regarding apprentices or "masters". The tailors, on the other hand, feared their small market sector for finer garments would be flooded, given

85. SAA, P OI4, I599.

86. Lis and Soly, "Corporatisme, onderaanneming en loonarbeid", pp. 377, 38I-387.

87. SAA, PK 682, 9 March I6oo.

88. SAA, Vierschaar (hereafter V) 1646,1602 and V I648, I632.

89. SAA, PK 757, I2 October 1660; PK 766, 21 February 1673. If the term "admittance to the guild" is to be interpreted as "becoming a master", then we can assume that the employment of journeymen as outworkers was no longer possible in this period. Otherwise, making them official "masters" would have been unnecessary. 
the weakened institutional barriers. Women were excluded from the guild during the seventeenth and eighteenth centuries. Tailors who made expensive products by special order did not need unskilled or semi-skilled help. As the workmanship and quality were far more important, they required reliable skilled labour. Therefore, tailors and second-hand clothes dealers were far more likely to subcontract to skilled master tailors. We do not know whether these masters were paid journeymen's or masters' rates. Tailors' journeymen clearly managed to organize a brotherhood and even staged a few strikes. No evidence remains of such practices among hosiers' journeymen. ${ }^{90}$

The guildsmen's attitude toward their journeymen and apprentices thus depended on the market segment in which they operated. Guildsmen producing standardized goods and serving a national or international market tried harder to restrict wages than their counterparts producing for the local market. ${ }^{91}$ This strategy enables comparative study over a longer term that transcends the context of guildsmen in the early modern period. ${ }^{92}$ Nineteenth- and twentieth-century social history has repeatedly shown that daily labour relationships in a firm are influenced by the nature of the market for which the company produces. In the early nineteenth century, for example, master craftsmen in Ghent did not object to the mutual aid societies of their male journeymen. Conversely, textile manufacturers who needed to be competitive on the international market employed mainly women and children, and opposed every form of autonomous organization among their workers to preclude any campaigns for higher wages. ${ }^{93}$ In the 1930s, Belgian managing directors of standardized export-oriented industries, such as steel and coal (which had to compete on the world market), strongly resisted more generalized social negotiations, which would undoubtedly have entailed pay raises. Producers from the food industry, construction, and

90. On the contrary, the Parisian journeymen hosiers working on knitting frames were highly organized: Cisie Fairchilds, "The Production and Marketing of Populuxe Goods in EighteenthCentury Paris", in John Brewer and Roy Porter (eds), Consumption and the World of Goods (London and New York, 1993), p. 234. See about confraternities of journeymen in general, David Garrioch and Michael Sonenscher, "Compagnonages, Confraternities and Associations of Journeymen in Eighteenth Century Paris", European History Quarterly, I6 (1986), pp. 25-45; Alfons K.L. Thijs, "Religieuze rituelen in het emancipatieproces van handwerksgezellen (zestiende-negentiende eeuw)", in Lis and Soly, Werken, pp. 23I-28I.

9I. Catharina Lis and Hugo Soly, "An Irresistible Phalanx": Journeymen Associations in Western Europe, $1300-1800 "$, in Catharina Lis, Jan Lucassen and Hugo Soly (eds), Before the Unions. Wage Earners and Collective Action in Europe, 1300-1850, Supplement 2 of International Review of Social History (Amsterdam, 1994), p. 37.

92. The importance of a long-term analysis has been stressed by Lis, Lucassen and Soly, "Introduction", in ibid., p. 6.

93. Kathlijn Pittomvils, "De Gentse maatschappijen van onderlinge bijstand in de eerste helft van de negentiende eeuw. Solidariteit, staking en/of segmentering?”, Belgisch Tijdschrift voor Nieuwste Geschiedenis, XXV (1994-1995), p. 462. 
chemical plants - branches serving the domestic market or offering higher quality goods - were far more conciliatory in this respect. ${ }^{94}$

The nature of an industry's sales outlets therefore affected the attitude of employers towards their labour. Of course, this aspect did not necessarily determine labour relationships between masters and journeymen or between labour and capital. Apart from this economic aspect, the shifting balance of power between labour and capital should also be taken into account (level of skills, demand for labour, organization within the workforce or among the employers).

\section{CORPORATIVE INVOLVEMENT}

Although we cannot cover every aspect of the relation between artisans and their guilds, we will establish a few tentative links between the types of products and qualities on the one hand and the form of guild regulation on the other. I will discuss some information about admission restrictions, corporative rules and the boards of the guilds.

Concerning the admission restrictions imposed by guilds, the secondhand dealers were the only group which did not prescribe an apprenticeship. Similar to other commercial guilds (mercers, innkeepers, etc.), the secondhand dealers did not require an official apprenticeship or master test. ${ }^{95}$ Therefore, the stronger autonomy of women in the guilds of the secondhand dealers may not be coincidental. ${ }^{96}$ The hosiers officially prescribed an apprenticeship but were in practice rather lenient towards semi-skilled workers aspiring towards mastership (at least from the late seventeenth century onwards). The tailors took the cultural capital of the apprenticeship and the master test quite seriously indeed. Nothing indicates that their quality criteria were easily met.

With respect to corporative rules, the guild of the second-hand dealers was far from a model of rigidity. As they engaged in subcontracting and sold goods others had made, they had no interest in strict rules. Like their counterparts among the mercers, they often clashed with other guilds because they transgressed monopolies. ${ }^{97}$ This does not mean, however, that they endorsed complete laisser-faire. Second-hand dealers were not supposed to own more than one shop, they agreed to observe rules which intended

94. Dirk Luyten, "Ontstaansvoorwaarden voor het corporatisme. Het model van het neocorporatisme in het licht van de Belgische ervaring uit de jaren dertig”, Tijdschrift voor Sociale Geschiedenis, I9 (1993), p. 336.

95. Deceulaer and Jacobs, "Qualities and Conventions".

96. See Daneel, "Handelaarsters in oude kleren", pp. 207-209.

97. Van Honacker, "De politieke cultuur van de Brusselse ambachten", p. I99. See also Harald Deceulaer, "Guilds and Litigation: Conflict Settlement in Antwerp (I585-1796)", in M. Boone and M. Prak, Statuts individuels, statuts corporatifs et statuts judicaires dans les villes européennes (moyen âge et temps modernes) (Leuven-Apeldoorn, 1996), pp. I7I-208. 
to curtail the sale of stolen goods, and tried to exclude ragmen or peddlers from their guild. ${ }^{98}$ We have already seen that hosiers did not have strict rules concerning apprentices or journeymen. Similar to other export trades from the southern Netherlands, hosiers maintained rather flexible corporative rules. ${ }^{99}$ The growth of stocking production in proto-industrial regions and in manufactures undermined guild control altogether. Regarding the tailors, one would expect that corporative controls would be stronger. Nevertheless, aside from tighter admission restrictions (apprenticeship, exclusion of women), no rigid impediments to entrepreneurial behaviour were implemented. Unlike in Paris, there was no fixed number of new masters or limitation on the number of journeymen. ${ }^{100}$ Rules about prices or quality control did not exist (although the guild could intervene in conflicts between a tailor and a client). For the (male) master-tailors, their guild seems to have arisen more or less as a framework of conventions or, in the words of Paul David: "mutually consistent expectations that enabled coordination to be achieved without centralized direction". ${ }^{\text {ror }}$

The final aspect of guild regulation to be discussed here concerns the board of the guilds. All guilds maintained an institutionalized type of delegation where a representative spoke on the group's behalf and used the collective capital to wield authority considerably in excess of his personal contribution. ${ }^{102}$ Guild deans, for example, figured prominently in processions, maintained contact with the urban political elite, and represented their guild in dealings with the public. I believe that interest in serving in various offices within corporative organizations depended in part on the nature of the market segment. If representation strategies were important, the social capital to be obtained through service as a guild dean was probably significant. Guildsmen who were less interested in accumulating social capital probably considered the time-consuming obligations of guild administration burdensome.

Members of the tailors' guild were certainly interested in serving as guild deans and even became involved in conflicts over this office. On a market for expensive clothes, where people depended on jobs commissioned by a wealthy public, serving as the dean of the tailors' guild must have been a

98. ARA, AB 677 bis, 9 July I703; SAA, PK 926, 30 December 1728; SAA, PK 821, 7 October I730.

99. J. Craeybeckx, "Les industries d'exportation dans les villes flamandes au XVIIe siècle particulièrement à Gand et à Bruges", Studi in onore di Amintore Fanfani, vol. 4 (Milan, 1962), pp. 427430, 445 .

I0o. In Paris every year no more than ten new master tailors were allowed, and a master could not work with more than six journeymen: Daniel Roche, La culture des apparences. Une histoire du vêtement (XVIIe-XVIIIe siècle) (Paris, 1989), p. 284. No such rules existed in Antwerp, Ghent, Leuven or Mechelen: ARA, GR OR, 435, 24 October 1780.

IOI. David, "Why are Institutions the 'Carriers of History'?", p. 208.

IO2. Bourdieu, "Economisch kapitaal, cultureel kapitaal, sociaal kapitaal", pp. 132-I33. 
powerful symbol of craftsmanship. ${ }^{103}$ In addition to the position's opportunities for associating with higher social circles, the social capital attached may have affected economic activity as well. Several tailors' invoices show that many guild deans for the tailors of Ghent served aristocratic or affluent clients. ${ }^{104}$ Investigating whether they attributed their social capital to economic success or vice versa is clearly difficult.

A different situation prevailed among the hosiers. In I6IO, this guild's former deans resisted a motion to modify the election procedure that would have relieved the current deans of their office. For twenty years, only one new dean had been appointed each year, and the other one in office had been "continued". Accordingly, the guild officials at the clothiers' hall had to select one of only two candidates. In an effort to "relieve the burden" from the persons nominated by the guild, the guild officials asked that four names be provided. The guild resisted this request, arguing that there was no reason to exempt the two nominees "in their favour" from their responsibilities as deans. One of the deans might very well have spent six years "serving the guild in various ways, such as dean, alderman, treasurer, or otherwise, which was ample reason for him to be excused". These measures would solve nothing, however, for if they were to appoint new people, such masters "would attempt similar forms of subterfuge". ${ }^{\text {ros }}$ This lack of enthusiasm was far from incidental. In 1627, tailor Willem Brems asserted that the hosiers' deans "cared so little for their office and did so little in this capacity that hardly anybody knew they were deans for the hosiers' guild". Moreover, "no guild had such ineffectual administrators as the hosiers". ${ }^{\text {ro6 }}$ A few years later, hosier Michiel Valckx also deplored the nonchalance of his deans. ${ }^{107}$ The impression that tailors and hosiers showed different ambitions towards serving on the board is confirmed by systematic analysis on six guilds in sixteenth-century Ghent. The tailor's guild appeared to be the most oligarchic, while the hosiers were the most democratic. ${ }^{108}$

Some petitions from ${ }_{1} 636$ provide a partial explanation for this lack of corporative involvement. Legal fees and repairs to their house had exhausted the guild's financial reserves. Each new dean's obligation to compensate his predecessor brought about "many attempts to avoid accepting the dean's office". Some very makeshift hosier's invoices from the 1630s, the 1650s, and

I03. A yearly almanac containing the names of the most important entrepreneurs of Ghent listed the names of the gezworenen or deans of the tailors: Nieuwen Almanach, curieus ende util voor het Jaer [.. . ] ofte den getrouwen wegwijzer der stad Gend, zoo voor de Vremdelingen als voor de Inwoonders der selve stad (Ghent, I770-I797).

I04. Universiteitsbibliotheek Gent, Vliegende Bladen, I, T 4, Jan De Clerck, Lambert Perenot and Simoen Rauwel could be identified as gezworenen or deans after checking the names of the officials on the membership lists: SAG, Reeks I9I-4.

I05. SAA, PK 699, August I6Io, f. IO0 v.-IOI r.

I06. SAA, V I647, I627.

I07. SAA, V I648, I632.

Io8. See the article by Johan Dambruyne in this volume. 
the 1660 s reveal that the guild was almost permanently in debt. ${ }^{109}$ This situation entailed major consequences for some guild deans: dean Jan Nilis had advanced 590 guilders for reparations to their hall, even though he "also needed his money for his own business". ${ }^{\text {IIo }}$ Advancing money to pay debts during the year was not the problem, as this practice was common to all guilds. Rather, the more capital-intensive nature of the hosiery trade explains the prevailing lack of corporative enthusiasm. Hosiers may also have worried less about their social reputation, as they served a broader and more anonymous public.

Several guilds operating in similar market sectors encountered the same problems. Deans for the Antwerp mercers frequently resisted extensions of their period of service and occasionally even paid Ioo guilders to be excused

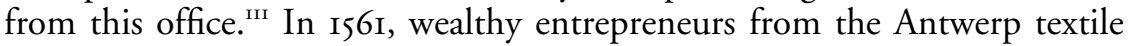
industry were accused of performing their guild duties reluctantly and of refusing to serve as deans. ${ }^{112}$

Likewise, many Antwerp silk weavers, who manufactured for the entire southern Netherlands and for export markets, were loath to become deans. Nor were the Antwerp carpet weavers known as corporative enthusiasts in the seventeenth century. ${ }^{\mathrm{II}}$ Was it sheer coincidence that the guildsmen from these industries all served large market sectors (the mercers) or maintained little direct contact with their clientele? These entrepreneurs needed the guild's social capital far less than small artisans filling orders for the local market. The difference between their markets may explain the corporative apathy of some guilds as opposed to the corporative zeal of others. The benefits of group membership clearly underlie a group's solidarity. ${ }^{\mathrm{II}}$ Economic profits resulting primarily from individual entrepreneurial strategies undoubtedly comprised corporative solidarity. Such trends may very well have increased towards the end of the eighteenth century. Market expansions probably made production in many sectors more capital-intensive and may have given guildsmen second thoughts about serving as the dean of a guild plagued by debts. The social capital attached to this position probably became less important to entrepreneurs in expanding markets. This develop-

I09. In the I630s, the debts fluctuated from 300 to 500 guilders a year; in the 1650 s two remaining accounts showed a shortfall of a bit more than Ioo guilders, while in the I66os the balance varied from +10 to -223 guilders: SAA, GA 4019.

IIo. SAA, PK, 735, f. 218, PK 737, 3 April I636.

III. Edmond Geudens, Het hoofdambacht van de meerseniers, I, Burgerdeugd (Antwerp, I903), pp. $50-55$.

II2. Etienne Scholliers, "Vrije en onvrije arbeiders voornamelijk te Antwerpen in de I6e eeuw", Bijdragen voor de Geschiedenis der Nederlanden, II (I956), p. 287.

II3. Thijs, Werkwinkel, pp. 213, 253. The coopers, butchers, and gold and silversmiths also showed signs of a loss of interest in their guild in this period: Floris Prims, Met Spanje (I555-I7I5, De Economische orde (Antwerp, I942), pp. 57, 87-88, II5.

II4. Bourdieu, "Economisch kapitaal", p. I33. 
ment may have played a role in the internal crisis in corporatism that affected some sectors. ${ }^{\text {II }}$

\section{LAST HONOURS}

Historians are well aware of the prominence of death in the early modern period. Rituals of mourning and praying for the souls of the deceased were of paramount importance. Contemporaries went to a great deal of trouble to organize funerals, and many guilds, neighbourhoods and brotherhoods had facilities for burying their members with dignity. ${ }^{116}$ In addition to their personal and religious importance, funerals were important social representations about the deceased and his or her family. We will identify differences in the representations between individual groups in the garment trades.

Eighteenth-century property statements enable a reconstruction of funeral expenses. Given the social differences between the subgroups concerned, the absolute figures yield insufficient information. Accordingly, the funeral expenses need to be relativized to reflect the overall balance of the inventories (Table 4). In both absolute and relative terms, tailors held more elaborate funerals than second-hand clothes dealers. A tailor spent an average of 3,785 groten on his own or his wife's funeral, whereas the (richer) secondhand dealers averaged only 2,80I groten. The tailors from this sample outspent the second-hand dealers by an average of $4 \mathrm{I}$ summer day's wages for a bricklayer's assistant. ${ }^{\text {II7 }}$

Hosiers also held less expensive funerals than the tailors, although they spent more than the second-hand dealers. Although these second-hand dealers were usually somewhat wealthier, their funerals must have been less ornate. Accordingly, spending on funerals was not directly proportional to income. A group's representation strategy seems to have been more significant. According to Lorna Weatherill, the "sober and industrious middling sort of people" in England spent relatively less on their funerals and weddings than other "traditional groups". ${ }^{18}$ Whether tailors were more traditional than the second-hand clothes dealers or the hosiers is questionable. The nature of the market in which these persons operated may have been a factor. Remarkably, Johannes Augustinus Block

II5. After the expansion of the market for shoes in the early nineteenth century, a lot of Hamburg shoemakers tried to avoid holding office in their guild: Petra Eggers, Das Konfliktverhalten Hamburger Handwerker von 1700 bis I860 (Dissertation zur Erlangung des akademischen Grades des Doktors der Philosophie an der Universität Konstanz, 1988), pp. 191, 203.

II6. Thijs, "Religieuze rituelen", p. 25I; Pittomvils, "De Gentse maatschappijen", p. 443. See also Jeremy Boulton, Neighbourhood and Society. A London Suburb in the Seventeenth Century (Cambridge, 1987), p. I49.

II7. Johan Dambruyne, "De Gentse bouwvakambachten in sociaal-economisch perspectief (I5401795)", in Lis and Soly, Werken, p. 65.

II8. Weatherill, Consumer Behaviour, pp. 64-65. 
Table 4. Absolute and relative cost of the funerals of tailors, hosiers and secondhand clothes dealers, Ghent, eighteenth century (in Flemish groten)

\begin{tabular}{|c|c|c|c|c|c|c|c|c|}
\hline Tailors & $\begin{array}{l}\text { Abs. } \\
\text { cost }\end{array}$ & $\begin{array}{c}\% \text { of } \\
\text { balances }\end{array}$ & $\begin{array}{l}\text { Second- } \\
\text { hand } \\
\text { dealers }\end{array}$ & $\begin{array}{l}\text { Abs. } \\
\text { cost }\end{array}$ & $\begin{array}{c}\% \text { of } \\
\text { balance }\end{array}$ & Hosiers & $\begin{array}{l}\text { Abs. } \\
\text { cost }\end{array}$ & $\begin{array}{l}\% \text { of } \\
\text { balance }\end{array}$ \\
\hline FB, 1702 & 2,908 & 23.9 & FDB, 1735 & 613 & 1.03 & $\begin{array}{c}\text { GVM, } \\
1731\end{array}$ & 8,480 & 0.3 \\
\hline JH, 1712 & 2,226 & 6.1 & PH, 1736 & 823 & 3.8 & $\begin{array}{l}\text { JVW, } \\
1737\end{array}$ & 2,498 & 15.8 \\
\hline JP, 1738 & 3,436 & 14.8 & WVG, 1736 & 1,080 & 1.8 & $\begin{array}{l}\text { ADC, } \\
1736\end{array}$ & 3,119 & 3.4 \\
\hline JD, 1738 & 1,736 & 27.8 & PG, 1738 & 976 & 4.8 & $\begin{array}{l}\text { PVH, } \\
1759\end{array}$ & 1,629 & 2.8 \\
\hline PDB, 1740 & 5,988 & 53.5 & PJH, 1738 & 1,996 & 1.5 & $\begin{array}{l}\text { LFM, } \\
1790\end{array}$ & 1,504 & $(2.3) ?$ \\
\hline FB, 1785 & 1,418 & $17.7 ?$ & SV, 1740 & 968 & 14.1 & & & \\
\hline $\mathrm{AB}, 1785$ & 2,584 & 1.9 & JD, 1780 & 9,858 & 1.7 & & & \\
\hline JAB, 1787 & 472 & $3.6 ?$ & JJC, 1786 & 7,345 & 7 & & & \\
\hline JL, 1789 & 13,304 & $(10.6) ?$ & JV, 1787 & 1,552 & 1.3 & & & \\
\hline
\end{tabular}

For the statements with negative balances, the percentage of the total balance appears between parentheses.

was the only tailor who had a simple funeral. During his lifetime, he had emulated the hosiers and second-hand dealers by targeting the market for inexpensive clothing. ${ }^{\text {II }}$

Understanding the significance of these expenditures requires a qualitative analysis. Costs that appear for all funerals involve the obligatory payments to the Alexianen brothers, who had the right to carry the coffin for a fee, and to the four boys from the orphanage, who carried the candles. In 1738, at the funeral of Joanne Staelens, the wife of tailor Jan Pauwels, six boys (rather than the usual four) participated. ${ }^{\text {I2O }}$ At the funeral of tailor Pieter De Buyne's wife, two pounds and eight shillings worth of bread was distributed among the poor. ${ }^{\text {I2r }}$ Several other tailors' testaments stipulated donations to the local indigence as well. ${ }^{122}$ Some had been members of a brotherhood and had paid their doodschuld (compensation for their peers' attendance of their funeral) in exchange for solemn honours. The candles of the Ghent orphans, the bread for the local poor, the guild's pall, the brotherhood's banner, and the presence of colleagues, fellow brotherhood members and neighbours when the coffin

II9. He had a stock of cheap clothing and owned a market stall: SAG, Reeks 332, 815, I9, 1787 .

I20. SAG, Reeks 332, 577, 8, I738.

I2I. SAG, Reeks 332, 587, 5, I740.

I22. We need not exaggerate this phenomenon: out of thirty-two Antwerp testaments, only four listed gifts to the poor: N II75, I6 January I59I and I4 October I59I; N 3357, 8 July I6IO and 2 August I6ro. 
was lowered into the sacred ground all symbolized the deceased's solid roots in the local community and honoured the widower, the widow and the children. Naturally, hosiers and second-hand clothes dealers also valued such testimonials. Many expenditures at their funerals were qualitatively identical to those of the tailors. In their specific market sectors characterized by faster transactions of cheaper garments, however, reputation and social capital were less vital than among the tailors. This context may explain why they spent less on funerals in both absolute and relative terms. We should also bear in mind that tailors, as typical representatives of the lower middle strata, were very concerned with status as a "last line of defence against proletarianization". ${ }^{23}$

\section{CONCLUSION}

Clearly, the social, institutional and cultural approaches of guilds and guildsmen need to be linked more closely with their daily economic practice. Without resorting to economic or monocausal explanations, I submit that the tremendous diversity between groups is partially attributable to economic differences. The nature of the market segment in which an individual operated offered options and imposed restrictions. Central elements in the actors' lives, such as their strategies for acquiring real estate, their labour relationships and the measure of their corporative involvement were intricately linked, along with their attitude towards funerals. Further exploration of such differences between groups of guildsmen would be an interesting area of research. Individual economic practice seems to have been largely path-dependent. Capital, accumulation, hereditary transfer, or acquired skills turned life into a series of choices and opportunities structured by one's social and economic position. ${ }^{\mathrm{I} 4}$

Hosiers invested mainly in economic capital. They had large stocks, used a putting-out system, and served a regional market. At first sight, tailors made very few "investments". Compared to other groups, they purchased more houses, devoted more time and energy to their guild, and arranged more splendid funerals for their family members. According to the traditional neoclassical economic perspective, hosiers seem to have been dynamic entrepreneurs who invested their means productively. The same conceptual framework would depict the tailors as "traditional" guildsmen who "squandered" their resources on houses, clothes, rites of passage, and corporative institutions. This rationale, however, focuses on economic capital. The tailors had their own spending logic. Many guildsmen and small

I23. Christopher Friedrichs, "Capitalism, Mobility and Class Formation in the Early Modern German City", in Philip Abrams and Edward Anthony Wrigley (eds), Towns in Societies. Essays in Economic History and Historical Sociology (Cambridge, 1978), p. 207.

I24. Bourdieu, "Economisch kapitaal, cultureel kapitaal, sociaal kapitaal", p. I2O. 
merchants viewed their local reputation as social capital essential to survive or to achieve a measure of affluence. ${ }^{125}$ This social capital could be converted to economic capital under certain conditions (Bourdieu). Because they depended on assignments, tailors primarily pursued the trust of potential clients. They cared deeply about their reputation and engaged in a marketing strategy avant-la-lettre through investments in relationships and reputations. ${ }^{126}$ The reproach by some contemporaries and historians that corporative meetings, banquets and parades were a waste of time and money reflects a logic based exclusively on economic capital. This criticism overlooks the importance of social capital to guildsmen in restricted market segments.

Understanding the multiformity of capital and investments ties in with the recent tendency in the social sciences to extend the analysis beyond purely economic investments. ${ }^{127}$ Without relapsing into a procrustean logic, the highly multiform strategies and behavioural attitudes of artisans seem much more interrelated through the collective logics or "conventions". The tailors can probably be categorized as a "domestic" or "person-oriented" group. The second-hand dealers were a "market-oriented" group within the guild system. Hosiers seem to reflect a product-oriented logic. Compromises between these different production spheres were possible, for example via subcontracting. To some extent, these conventions of individual economic behaviour were linked to certain types of (collective) guild regulation. ${ }^{128}$ Although we cannot explore the historical evolution of the three groups in detail here, the historical trajectories of the different guilds and groups of artisans seem to have varied according to their dominant "conventions". The person-oriented tailors were not unaware of processes of commercialization, but their historical evolution was somehow less dramatic than that of the hosiers. Comparable to other product-oriented groups in the "industrial" convention (linen weaving, hat making), the hosiers underwent important structural changes in the eighteenth century. The second-hand dealers, in particular, engaged in commercial conflicts with other artisans and pedlars.

Regarding the debate about classifying guildsmen, a priori categorizations based on corporative membership, occupation or property seem highly presumptuous, as such general criteria often conceal very divergent professional

I25. Boulton, Neighbourhood and Society, pp. 226, 232; David Garrioch, Neighbourhood and Community in Paris, I740-I790 (Cambridge, I986), pp. 33, 37, 38, 40; Martin Dinges, "Frühneuzeitliche Armenfürsorge als Sozialdisziplinierung? Probleme mit einem Konzept", Geschichte und Gesellschaft, I7 (1991), pp. 20-26.

I26. [. . .] "investissements relationels et de prestige" [. . .] "qu'il n'est pas possible de lire directement en terme d'utilité économique": Simona Cerutti, La ville et les métiers. Naissance d'un langage corporatif (Paris, 1990), pp. 49-5I.

I27. For example, Bourdieu, "Economisch kapitaal, sociaal kapitaal, cultureel kapitaal", passim;

Thévenot, "Economie et politique de l'entreprise", pp. 135-207.

I28. Compare Deceulaer and Jacobs, "Qualities and Conventions". 
or commercial identities. Nevertheless, we need not abandon all efforts to establish a connection between production environments, labour relationships, lifestyles and institutional configurations. Considering the daily economic practice of guildsmen, investigating the market sectors they served might offer a means for tracing these links. 